\title{
Creation of the fictional world in The Witcher 3: Wild Hunt
}

\section{Krzysztof Jański}

University of Wroctaw | krzysiekjanski@wp.pl

\begin{abstract}
The article focuses on worldbuilding techniques used in The Witcher 3: Wild Hunt in order to create a self-contained fictional world. Firstly, an overview of the characteristics of game spaces is provided. Secondly, following a brief introduction to Andrzej Sapkowski's fiction, the article discusses the design methods the game uses for representing topography, architecture, human and nonhuman activity, as well as for providing background information about various locations. It is concluded that the game space may be seen as an independent ontological construct and not only a framework for gameplay.
\end{abstract}

Keywords: worldbuilding, video games, The Witcher 



\section{Introduction}

The immense success of The Witcher game series (2007-2016), and in particular its final installment, excited much interest for the characters and settings which make up that which is popularly referred to as 'the Witcher's universe'. The games fall within the cRPG genre and focus on the character of Geralt, a professional monster slayer. They are set in a medievalesque, low-fantasy world which is an adaptation ${ }^{1}$ of Andrzej Sapkowki's prose. The Polish writer published two collections of short stories and six novels that revolve around Geralt's adventures. Since their release, Sapkowski's books became a phenomenon, especially in Poland, but also in a number of other countries. The acclaim the books earned is traced by critics, for instance, to an ingenious employment and transformation of various themes and genres combined with the skilled use of irony and humour (Wróblewska, 2015, p. 96), or to the successful encouragement of readers to tackle difficult contemporary issues from a safe distance, through the lens of fantasy that, nonetheless, remains grounded in reality (Gemra, 2001, p. 185). Notwithstanding, The Witcher as a franchise gained exponentially growing international popularity only after the release of the games.

The aim of this article is to discuss the worldbuilding methods employed by CD Projekt Red in the development of The Witcher 3: Wild Hunt $^{2}$ (including the two official expansions, Heart of Stone and Blood and Wine) in order to indicate how the game contributed to the growth of the franchise, primarily through the introduction of extensive, selfcontained fictional spaces whose purpose extends beyond the necessity of providing a framework for the gameplay and narrative. The discussion is limited to official material only and aims to avoid references

1 It is important to note that the game series is not an adaptation per se, but rather a spin-off. Sapkowski fervently stands by his conviction and denies that the in-game content, being an adaptation, is in any way canonically related to the books. The author states that "in no way can it be considered to be an 'alternative version', nor a 'sequel' to the witcher Geralt stories. Because this can only be told by Geralt's creator. A certain Andrzej Sapkowski" (Purchase, 2012). Without raising the poststructural questions about authorial intent, there is no doubt that the games are currently embraced as canon (or part of 'the Witcher's universe') by the majority of fans.

2 Abbreviated to TW3. 
to other works in The Witcher franchise (graphic novels, film adaptations, role-playing games, board games). This restrictiveness is motivated by reasons of space and on the grounds that, arguably, TW3 offers players a well-developed world. Moreover, as Maria Garda accurately noted, the source of worldbuilding in 'the Witcher's universe' has clearly shifted from Sapkowski's fiction to the new media (2010, p. 25), games in particular. Considering its size, $\mathrm{TW}_{3}$ aspires to be a major contributor to the expansion and actualisation of the world of The Witcher franchise and, in fact, succeeds in doing so by providing much required content: a vast, immersive virtual topography that supports a plenitude of events, characters and supplementary lore.

\section{Worlds in Video Games}

With our focus on spaces in TW3, it seems reasonable to cite Espen Aarseth, who in the paper "Allegories of Space" makes a claim that "the defining element in computer games is spatiality" and continues that "games are essentially concerned with spatial representation and negotiation" (2007, p. 44). This seems particularly relevant when we consider a vast, open-world game such as TW3. Aarseth posits that video game spaces are in fact not spatial, but, as a result of a reductive operation, symbolic and bound by mechanics, which makes gameplay possible (2007, p. 45). By involving the concept of allegory, he concludes the article stating that games "pretend to portray space in ever more realistic ways, but rely on their deviation from reality in order to make the illusion playable" (2007, p. 47). In other words, game spaces imitate a kind of a reality in order to support the mechanics and gameplay.

The relationship between an illusionary world of a video game and the game mechanics lies at the heart of game studies. In his seminal Half-Real (2005), Jesper Juul articulates an important distinction, namely, that rules in games are always nonnegotiable, while fictional elements, if present, are always arbitrary and incomplete. Therefore, for a ludologist, worldbuilding serves an ancillary purpose. Jan-Noël Thon, a representative of narratologists, comments on fictional worlds in video games: 
All presentations of fictional worlds are necessarily incomplete and players - adhering to what is known as the "reality principle" (...) or the "principle of minimal departure" (...) - use their world knowledge to 'fill in the blanks' when trying to imagine these worlds. While the question of how we construct mental representations of fictional worlds is certainly relevant, it has to be emphasized that fictional worlds are neither their medial presentations nor their mental representations (2009, p. 2).

Thon reiterates and adjusts to a new medium Wolfgang Iser's (1995) influential phenomenological approach to fiction, wherein the meaning of a text is an end-product of the material the author provides; the material whose elements are always to an extent incomplete, and the reader's creative participation, i.e. the introduction of subjective contributions, is necessary to resolve the text's indeterminacy. In other words, reception of video games is a result of negotiations between the (audiovisual) material, (fixed) mechanics and player's participation.

In consideration of the above, Michael Nitsche proposes a method of analysing game spaces which reconciles the preferences of narratologists and ludologists. His comprehensive model accounts for the game mechanics, the player's subjective contribution and their interaction with the game, as well as with other players. He divides game spaces into five planes, all of which are required in order to produce enjoyable gameplay: rule-based space, mediated space, fictional space, play space, social space (2008, p. 15-16). Let us consider Nietche's comments on the interaction between the first three:

The rule-based space is defined by the code, the data, and hardware restrictions. It is the world of the functional restrictions that often mirror architectural structuring of video game spaces. This world is the basis for the mediated space, which consists of all the output the system can provide in order to present the rule-based game universe to the player. In the case of commercial video games this layer consists mainly of audiovisual and tactile output that provides a form of presentation. The player is confronted with this presentation and imagines a world from the provided information - the fictional space. Based on the fictional world players decide on actions to affect the game space (2008, p. 16).

The following discussion of worldbuilding in $\mathrm{TW}_{3}$ is narrowed down to the first three planes, with a particular emphasis of the second one.

As pointed out above, fictional worlds are by their nature incomplete. While various media have their own means of diminishing any existing 
indeterminacies (some common methods being the convergence of other media or the utilisation of the recipient's prior knowledge, experience and expectations related to the medium or a genre), video games most notably make use of such mechanisms as interactivation, visualisation, auralisation, to apply the terminology proposed by Mark J. P. Wolf in Building Imaginary Worlds (2012). Therefore, they are capable of rendering refined, believable fictional environments as sets for stories within the available, yet ever-expanding technological boundaries. Some critics also indicate the potential for video games to excel in building worlds. For example, Henry Jenkins argues, video games "may more fully realize the spatiality of these stories, giving a much more immersive and compelling representation of their narrative worlds" (2002, p. 5). We may also refer to Lev Manovich, who in a relatively early survey of new media considers "navigating through space [in a video game], both as tool of narration and of exploration" and adds that "exploring the game world, examining its details and enjoying its images, is as important for the success of games such as Myst and its followers as progressing through the narrative" (2001, p. 247). These observations are particularly accurate when we consider CRPG as a genre, where much emphasis is placed on the well-developed structure of the constructed world which offers players many a location to investigate.

\section{Worldbuilding in TW3}

\subsection{Source Material}

Because TW$_{3}$ is an extrapolation from the literary setting created by Sapkowski, it is difficult, or even counterproductive, to completely avoid reference to the books. However, it must be underscored that a detailed discussion of the source material emergent from the short stories and novels is beyond the scope of this article. And at any rate, the background information of the originals is scarce. As such, it proves to be insufficient for Geralt's adventures to be regarded as set in a full-fledged fictional world, in particular in the context of organised spatiality. This assertion reflects what Sapkowski admitted himself in an interview, reiterating 
that he created "a pseudo-world, merely a background" which "is a certain ontological construct, but which is ancillary to the plot and not its own fantastically bizarre ontology"3 (Bereś, Sapkowski, 2005, p. 274). It seems that Sapkowski was aware that his creation lacks the detail many other fantasy worlds have: an abundance of content, a consistent history and mythology, an organised fictional space. ${ }^{4}$ The image that emerges from the prose is that of a gritty, low fantasy setting imbued with moral ambiguity, brutality, racial and religious prejudice and persecution typically associated with the Dark Ages. Sapkowski also draws heavily on Slavic folklore and demonology ${ }^{5}$ which he combines with Arthurian and Nordic material, more typical of fantasy as a whole; furthermore, the novels and short stories are highly intertextual. ${ }^{6}$

Sapkowski's writing style is drawn-out, yet even though some of his descriptions of characters and locations may be picturesque and lengthy (interestingly, many of such descriptions appear to be used only for aesthetic or rhetoric purposes and ultimately prove to serve as introductions of episodic, irrelevant places, characters or histories which play an incidental role in the main plot), most are rather laconic. For instance, one can try in vain to find a detailed depiction of Geralt. What stands out the most in the author's style is how talkative, witty and philosophical his characters are: extensive dialogues are one of Sapkowski's chief worldbuilding methods and, therefore, serve as a major source of character and setting exposition. While these features make for an interesting read, they are not so useful for developing a systematic setting. In particular, due to a lack of a metatextual spatial framework, it is difficult to map these rather incidental descriptions of locations and events.

${ }^{3}$ Author's translation.

4 Unlike authors who create detailed worlds for their fiction, Sapkowski did not prepare maps for his setting. Whereas the first maps were drawn by fans in collaboration with the author, the first official maps were only appended to the games.

5 For a discussion of motifs borrowed from Slavic mythology in Sapkowski's texts, refer to Paweł Zaborowski's article "Mitologia słowiańska w cyklu o wiedźminie" (2015).

6 The description is necessarily succinct. For a extensive discussion, see the pioneering work by Katarzyna Kaczor, Geralt, czarownice $i$ wampir (2006), which offers a detailed description of characters, plot patterns, inspirations and motifs. For an in-depth analysis of intertextuality, in particular of the borrowings contained in mottos or stylised excerpts provided by Sapkowski before each chapter, refer to Maciej Kuster's article (2015). 


\subsection{In-game Worldbuilding Techniques}

As inspiring and successful as Sapkowski's writing might have been, the characteristics of the literary originals (the dominant role of dialogues, the patchwork nature of the created setting, the limited source material, but also Polish folk, which may be regarded as 'exotic' by foreign recipi$\left.e t^{7}\right)$ posed a number of challenges for CD Projekt from a game development standpoint. For instance, by transferring the setting to another medium intended for an international audience, the developers had to ensure that the world they present is attractive to all potential recipients: both those familiar with and new to Sapkowski's writing and the previous games in the series. TW3 assumes that the player is familiar with the key characters and the specifics of the setting. Newcomers are provided with an in-game summary of lore, either delivered via dialogues (and notably a lengthy exposition of the nature, history and politics of the world offered after the prologue sequence) or journal entries. Despite this, initially TW 3 may be overwhelming and confusing to new audiences, as it requires a degree of familiarity with the setting. This is largely attributable to the game being a part of a larger franchise. In this regard, TW 3 is an example of situation discussed by Jenkins where a game offers an independent experience (and its game spaces are a useful tool to unfold immersive and memorable narratives), yet the entirety of the narration is only available when we peruse other media which form a larger narrative system (2002, p. 7).

The game makes use of audio-visual effects and interactivity to construct its world. ${ }^{8}$ Regarding the graphics and the music in TW3 (after passing the minimum hardware requirements threshold), the game's engine is capable of generating compelling, picturesque environments. To quote Wolf and his categorisation of game spaces, TW3 presents us

7 TW3 returns to a more Slavic aesthetic, after a departure towards a more generic fantasy art style of The Witcher 2 .

8 Still, the game remains somewhat faithful to the original in its dependence on dialogues (both interactive and cut-scenes). TW3 is a fully voice-acted game and the number and runtime of dialogues and cut-scenes is sometimes criticised as being too extensive. On the one hand, this may be regarded as having a potentially negative influence on the game's reception; at times the game may resemble an interactive film. On the other hand, the well-acted dialogues offer much information about characters, locations, quests, etc., contributing to the overall shape of the world. 
with an 'interactive three-dimensional environment' in which "spaces and the objects in them can be viewed from multiple angles and viewpoints, which are all linked together in such a way as to make the diegetic world appear to have at least enough spatial consistency as to be navigable by the player" (Wolf 1997, p. 20). The presented locales are a digital actualisation of a portion of the setting which may be inferred from Sapkowski's writing, albeit it must be noted that the virtual spatiality of the locations is almost entirely the product of the developer's efforts. According to the claims CD Projekt made, no part of the virtual environment was generated automatically (Klepek, 2015). The game boasts a vast, semi-open world that is composed of several regions accessible by fast travel. The regions are divided as follows: two small locations, White Orchard and Royal Palace in Vizima (the latter mentioned in the books and present in the first Witcher game); two connected massive areas, Velen and Novigrad (the latter described in the books); and three large areas, Skellige, Toussaint and Kaer Morhen (all settings for events in the books).

Considering its scope, the world depicted in TW3 is well-constructed, despite certain shortcomings largely determined by today's technical limitations. Moreover, as numerous relevant themes of Sapkowski's writing were transferred to the game (in particular the harsh realities and moral ambiguities of the setting), it is successful in encapsulating the atmosphere of the originals. In order to diminish the shortcomings of the rendered game spaces and conceal any gaps in their immersive backdrop, CD Projekt made use of the assumed players' prior knowledge, experiences and expectations. Similarly to the literary originals, TW3 adapts (but also subverts) elements typical of medieval-based fantasy in general, cRPG as a genre, but also common-sense expectations of audiences derived from the primary world.

The game offers a broad selection of unique locations: there are marshes, forests, plains, rivers, seas, lakes, hills, mountains, villages, and larger settlements, including sprawling cities consisting of various idiosyncratic districts and relevant infrastructure. Each major location is characterised by an overriding theme. Velen (also referred to as No Man's Land) is a predominantly marshy and foresty area inhabited chiefly by stricken villagers living in various scattered settlements. It is also a site of an upcoming clash between Redania and Nilfgaard, the 
two major political forces in the background of TW3. Velen is a rendition of an impoverished Polish countryside. The Free City of Novigrad is a large, prosperous port: it is a centre of trade and commerce, divided into numerous districts for the rich and the poor, full of vendors and providers of various services. The city is inhabited by various people, including nonhumans, and is an arena of religious and racial turmoil akin to the workings of the primary world's inquisition. Skellige is an archipelago of mountainous islands ruled by Viking-like people, broken into conflicting clans, a harsh folk who are primarily fisherman, sailors and costal raiders. The overall atmosphere, the architecture, the aesthetics of the ships and gear (e.g. the islanders use drakkars) as well as the political system and religious beliefs of the isles draw heavily on Scandinavian themes. Finally, Toussaint is a prosperous duchy, which is not spoilt by war, and is famous for superb wines and knights-errant who guard its borders. The major sources of inspirations for this location are French geography and culture and the tradition of chivalric romances. In addition to the abundance of landscapes, the locations represent various climates (the temperate climate of Velen/Novigrad resembling Central Europe, the cold climate of Skellige resembling Scandinavia, the warm climate of Toussaint resembling Southern France) and the game uses a dynamic day, night and weather cycle to add to the rendered game spaces' realism. Moreover, on certain occasions, the game references realms and events outside of its depicted world, but within the setting drafted by Sapkowski, which offers a sense that the areas represented in $\mathrm{TW}_{3}$ are a part of a larger construct.

The developers implemented many architectural solutions to TW3. For a discussion of the creation of game spaces and their functions let us refer to Enest W. Adams' article, “The Construction of Ludic Spaces”, in which he juxtaposes real-world architecture with video game architecture. The author contends that the primary function of virtual spatiality is the support of gameplay mechanics; however, he also admits that a fictional world "has a secondary, and still highly valuable role to play: to inform and entertain in its own right" (2003, p. 12). With our emphasis on worldbuilding (i.e. mediated and fictional spaces), let us take a closer look at Adams' secondary functions of architecture in games and examples of how these were employed by CD Projekt in the development of TW3. 


\begin{tabular}{|c|c|c|}
\hline Function & Description of function & Example in TW3 \\
\hline $\begin{array}{l}\text { Familiarity (or } \\
\text { architectural } \\
\text { clichés }^{9} \text { ) }\end{array}$ & $\begin{array}{l}\text { "Familiar locations offer cues } \\
\text { to a place's function and the } \\
\text { events that are likely to oc- } \\
\text { cur there" (ibid., p. 12). }\end{array}$ & $\begin{array}{l}\text { Borsodi's' Auction House: players may } \\
\text { infer that an auction will be held in } \\
\text { the building and that they will be able } \\
\text { to purchase exotic items. }\end{array}$ \\
\hline Allusion & $\begin{array}{l}\text { "Game architecture can make } \\
\text { reference to real buildings or } \\
\text { architectural styles to take } \\
\text { advantage of the ideas or } \\
\text { emotions that they suggest" } \\
\text { (ibid., p. 13). }\end{array}$ & $\begin{array}{l}\text { Novigrad: the various districts and } \\
\text { landmarks (the market square, port, } \\
\text { temple district) have their unique ar- } \\
\text { chitectures which help to establish the } \\
\text { background of the city (e.g. the wealth } \\
\text { of the dwellers, the function of lo- } \\
\text { cations). Also, the crane in Novigrad } \\
\text { resembles the crane in Gdańsk. }\end{array}$ \\
\hline Novelty & $\begin{array}{l}\text { To cause a sense of unfa- } \\
\text { miliarity, lack of a frame } \\
\text { of reference (ibid., p. 14). }\end{array}$ & $\begin{array}{l}\text { The alien landscapes visited during the } \\
\text { "Through Time and Space" quest. }\end{array}$ \\
\hline Surrealism & $\begin{array}{l}\text { "Surrealism creates a sense } \\
\text { of mystery and more impor- } \\
\text { tantly, it warns the player } \\
\text { that things are not what } \\
\text { they seem" (ibid., p. 15). }\end{array}$ & $\begin{array}{c}\text { The uncanny, fairy tale locations and } \\
\text { buildings in the "Beyond Hill and Dale" } \\
\text { quest. }\end{array}$ \\
\hline Atmosphere & $\begin{array}{l}\text { This function aims at evoking } \\
\text { specific emotions (ibid., } \\
\text { p. 16) }\end{array}$ & $\begin{array}{l}\text { Kaer Morhen, a derelict keep where } \\
\text { witchers used to be trained. The state } \\
\text { of disrepair of the once grand fortress } \\
\text { adds to the feeling of nihilism which } \\
\text { pervades the entire universe. }\end{array}$ \\
\hline Comedic effect & $\begin{array}{l}\text { "Not all game worlds are } \\
\text { familiar, dangerous, or } \\
\text { strange; some are supposed } \\
\text { to be lighthearted and funny" } \\
\text { (ibid., p. 16) }\end{array}$ & $\begin{array}{l}\text { Difficult to find, but arguably the entire } \\
\text { Toussaint area, with its light-hearted } \\
\text { theme and overdrawn, professional } \\
\text { knights-errant (who receive pay for } \\
\text { their deeds from the Ducal Camerlengo } \\
\text { or who corrupt the ideals of chivalry). }\end{array}$ \\
\hline
\end{tabular}

\section{The functions are used with varying frequency but they all contribute} to the creation of an immersive world. However, not only spaces and architecture are employed to that end. TW3 uses typical cRPG devices used for representing human activity. Villages and urban areas are densely inhabited by NPCs preoccupied with various business. Their

9 Considering that TW3 represents the fantasy genre, it seems that we may without loss collapse these two functions into one. Adams himself notes their proximity, commenting that architectural clichés are a "variation on the principle of familiarity, without the benefit of being informed by real-life examples" (ibid., p. 17). 
appearance and manner of speaking are adjusted to fit the nature of the place they live in, their social class and profession (or lack thereof). Elves, dwarves or Nilfgaardians will also speak in their unique, respective languages. ${ }^{10}$ Moreover, NPCs perform activities suitable to their status and occupation. By doing so, they drop hints on how the fictional world they inhabit may function. All of this takes place in the background and may be to a great extent ignored, but it offers an illusion of a world which is alive. In performing their daily routines NPCs also utter a number of lines; for instance, they comment on the weather, provide information about local lore, speak of superstition and traditions, spread gossip or comment on the player's actions (regarding a completed quest, which changes the dynamics of the region or the entire world ${ }^{11}$ ). As a rule, NPCs also react to the presence of the player's avatar: they try to sell goods, make comments about the odd looks of the avatar or insult him. This adds to a sense of depth of the in-game world and reduces a sense that its function is just to support the game mechanics and primary narration.

What further complements the complexity of the game spaces in $\mathrm{TW}_{3}$ is the information about all human settlements provided by the developers in the form of short notes accessible via the world map by hovering the cursor over fast travel icons. Players may also find message boards which, from a mechanical perspective, are sources of quests, but also display local adverts (which do not initiate quests) adding flavour and

10 Unlike Tolkien, Sapkowski did not create fully fledged languages. The languages we can hear in the games are therefore invented by the developers based on existing languages and samples of utterances invented for the purposes of the books. Noteworthy are the fans' attempts to create a dictionary of Hen Llinge; an example is available at http://witcher. wikia.com/wiki/Elder_Speech.

11 Although the article avoids reference to community-created content, it is important to expand upon Jenkins' remarks on convergence cited above to indicate the community's impact on the reception and shape of a fictional world, in particular that of a game as large as TW3. In Convergence Culture, Jenkins writes that "to fully experience any fictional world, consumers must (...) chase down bits of the story across media channels, compare notes with each other via online discussion groups, and collaborate to ensure that everyone who invests time and effort will come away with a richer entertainment experience" (2006, p. 21). The game's world is vast and even a single playthrough is time-consuming (according to submissions on HLTB, a completion of the main story and extras, excluding the expansions, takes on average in excess of 100 hours). Thus, in order to explore the world created by CD Projekt more fully, the players will have to resort to discover the in-game content in different channels (e.g. message boards, Reddit, YouTube). 
creating an impression that there is a functioning society that exists in the background, regardless of the player's actions and beyond the game's mechanics. In addition, TW3 offers information about locations and characters (but also politics, history, religion, etc.) in the form of journal entries, which may be revised later, ${ }^{12}$ or through books, letter, notes and the like, scattered throughout the world (these are often associated with side-quests or points of interest). The abovementioned details rarely have any bearing on the plot, yet their purpose is to offer a sense that the world is a multi-layered construct emulating the primary world's complexities. This method of worldbuilding contrasts an approach often assumed in cRPGs, whereby there are only disjoined locations necessary for the gameplay, tied to the main narrative, not rarely organised into 'hub' cities surrounded by swathes of wilderness. There are instances when the shortcomings of the game are laid bare and the reception of the rendered world is distorted; yet most of these may be traced to technicalities. ${ }^{13}$ For example, there is a limited number of NPC models (which becomes most starkly obvious during quests, when players happen to encounter two identical-looking characters who are in fact different NPCs) who utter a limited number of lines or who, in the majority of situations, fail to react when the player's avatar enters their property and loots their personal belongings. Another issue may be traced to enemies, and especially bandits, who insist on attacking Geralt head-on, in spite of the fact that they should recognise that they challenge a hardened, well-equipped witcher. ${ }^{14}$

Finally, the game also represents spaces ruled by nature. In the wilderness, specific areas are habitats to wild animals and monsters who behave in ways typical of their species, as suggested by primary world knowledge or intuition stemming from folklore. These creatures usually correspond to the type of environment they inhabit; e.g. drowners and

12 The in-game journal may serve as a concise Witcher encyclopedia, as it records a player's progress and often refers to lore outside of the game. All entries are written in a stylized manner, as created by Dandelion, a bard and one of the major characters.

13 The discussion is limited to the game "as intended", therefore this article does not consider possible glitches and bugs that may further affect a player's reception.

${ }_{14}$ Although these encounters are motivated by game mechanics (questing and levelling systems), situations like these may have a negative bearing on immersion, as well as the consistency of the created world. 
waterhags are found near water reservoirs or bogs; ghouls and wraiths are located in the vicinity of human remains; leshen dwell in forests; animals hunt in the wilds, wolves in packs and bears in solitude. Thanks to this, encounters with wildlife do not seem out of place. Apart from fighting monsters or bandits during travel from one location to another, there is much to be discovered off the beaten track, as the world is dotted with points of interest which encourage exploration. Similarly to the case of human settlements, many seemingly insignificant locations in the wilds have their back stories, often introduced through a discovery of a note or letter (or a related flavoured side quest), which adds depth and realism to the setting.

\section{Conclusions}

The article outlines and summarises the major world-building devices used by CD Projekt to craft believable fictional spaces in TW3. By making use of the available resources (often resolving to intertextuality and transmediality, drawing from Sapkowski's originals, as well as other works of popular culture), of the heritage of CRPG as a genre and of their own creativity, the developers successfully managed to bring Sapkowski's creation to life by producing a detailed, generally consistent ontological construct. It is important to bear in mind that in order to experience the world in TW3 more completely, a certain degree of familiarity with the franchise is required, though the game offers assistance to newcomers in diminishing the gap of knowledge between the player and the in-game material. The diverse environments, including historiographical, sociological and political backgrounds, are an artistic rendition of the scarce source material and offer sufficient content to create a holistic simulation of a believable, organic medieval fantasy world, which in its complex structure turned out to be much more than merely a scaffolding to support the gameplay and plot. ${ }^{15}$ They are also a major contribution to the

15 Considering the extent and detail of the world created, one might get the impression that CD Projekt created a world for its own sake. The task of exploring large areas of the map is left for the players' curiosity alone because from a mechanical perspective the game provides little to none incentive to do so. Firstly, the main quests and major side quests 
development of the lore of The Witcher franchise and the depth of that franchise's budding universe.

\section{References}

Aarseth, E. (2007). Allegories of Space. The Question of Spatiality in Computer Games. In Borries, F., et al. (Eds.). Space Time Play. Computer Games, Architecture and Urbanism: The Next Level (p. 44-6o). Basel: Birkhäuser Publishing.

Adams, W. E. (2003). The Construction of Ludic Spaces. Online: <https:// pdfs.semanticscholar.org/c898/00458c6e1ec6f1ef308c6b34c3fo339 dbd84.pdf>.

Bereś, S., Sapkowski, A. (2005). Historia i fantastyka. Warszawa: SuperNowa.

Garda, M. (2010). Gra The Witcher w uniwersum Wiedźmina. Homo Ludens, 2(1). Online: <http://ptbg.org.pl/HomoLudens/vol/2/>.

Gemra, A. (2001). Fantastyka po polsku. Kilka uwag nad twórczością Andrzeja Sapkowskiego. Europa Orientalis, 20(1), 167-185.

Iser, W. (1995). Interaction Between Text and Reader. In: A. Bennett (Ed.), Readers and Reading (p. 20-31). London: Longman.

Jenkins, H. (2002). Game Design as Narrative Architecture. Online: <http://paas.org.pl/wp-content/uploads/2012/12/o9.-Henry-Jenkins-Game-Design-As-Narrative-Architecture.pdf>

Jenkins, H. (2006). Convergence Culture: Where Old and New Media Collide. New York: NYU Press.

Juul, J. (2005). Half-real: Video Games between Real Rules and Fictional Worlds. Cambridge: MIT Press.

Kaczor, K. (2006). Geralt, czarownice, wampir. Recykling kulturowy Andrzeja Sapkowskiego. Gdańsk: słowo/obraz terytoria.

Klepek, P. (10 June 2015). How The Witcher 3's Developers Ensured Their Open World Didn't Suck. Kotaku. Online: <http://kotaku.com/how-the-witcher-3s-developers-ensured-their-open-world-1735034176>. 
Kuster, M. (2015). Sylwa, palimpsest, intertekst. Modele zapożyczeń intertekstualnych w „Sadze o Wiedźminie”. In: R. Dudziński, J. Płoszaj (Eds.), Wiedźmin - bohater masowej wyobraźni (p. 9-20) Wrocław: Stowarzyszenie Badaczy Popkultury i Edukacji Popkulturowej „Trickster”. Online: <http://tricksterzy.pl/download/wiedzmin-polski-fenomen-popkultury/>.

Manovich, L. (2001). The Language of New Media. Cambridge: MIT Press. Nitsche, M. (2008). Video Game Spaces: Image, Play and Structure in 3D Game Worlds. Cambridge: MIT Press.

Purchase, R. (07 November 2012). Ever wondered what the author of The Witcher books thinks about the games? Eurogamer.net. Online: <http:// www.eurogamer.net/articles/2012-11-06-ever-wondered-what-the-author-of-the-witcher-books-thinks-about-the-games>.

Thon, J. N. (2009). Computer Games, Fictional Worlds, and Transmedia Storytelling: A Narratological Perspective. Online: <https://www.academia.edu/3418208/Computer_Games_Fictional_Worlds_and_Transmedia_Storytelling._A_Narratological_Perspective>.

How long is The Witcher 3: Wild Hunt? - HLTB. Online: <https://howlongtobeat.com/game.php?id=10270>.

Wolf, M. J. P. (1997). Inventing Space: Toward a Taxonomy of On- and Off-Screen Space in Video Games. Film Quarterly, 51(1), 11-23.

Wolf, M. J. P. (2012). Building Imaginary Worlds: The Theory and History of Subcreation. New York: Routledge.

Wróblewska, A. (2016). Jak napisać bestseller? O genezie popularności Wiedźmina z perspektywy socjologii literatury In: R. Dudziński, J. Płoszaj (Eds.). Wiedźmin - Polski fenomen popkultury (p. 87-99). Wrocław: Stowarzyszenie Badaczy Popkultury i Edukacji Popkulturowej „Trickster”. Online: <http://tricksterzy.pl/download/wiedzmin-polski-fenomen-popkultury/>.

Zaborowski, P. (2015). Mitologia słowiańska w cyklu o wiedźminie. In: Dudziński, R. et al. (Eds.) Wiedźmin - bohater masowej wyobraźni (p. 21-32). Wrocław: Stowarzyszenie Badaczy Popkultury i Edukacji Popkulturowej „Trickster”. Online: <http://tricksterzy.pl/download/ wiedzmin-polski-fenomen-popkultury/>.

All online sources accessed on 31 December 2016. 


\section{Ludography}

CD-Project Red (2007). The Witcher [PC]. CD Projekt, Poland.

CD-Project Red (2011). The Witcher 2: Assassins of Kings [PC]. CD Projekt, Poland.

CD-Project Red (2015). The Witcher 3: Wild Hunt [PC]. CD Projekt, Poland.

CD-Project Red (2015). The Witcher 3: Wild Hunt, Hearts of Stone [PC]. CD Projekt, Poland.

CD-Project Red (2016). The Witcher 3: Wild Hunt, Blood and Wine [PC]. CD Projekt, Poland.

Krzysztof Jański M. A. - doctoral candidate at the Department of English Studies, University of Wroctaw.

\section{Budowa fikcyjnego świata w grze Wiedźmin 3: Dziki Gon}

Abstrakt: Celem artykułu jest przedstawienie metod tworzenia świata wykorzystanych w grze Wiedźmin 3: Dziki Gon, które pozwoliły na wypracowanie samodzielnej fikcyjnej konstrukcji. Pierwsza część tekstu omawia cechy miejsc w grach wideo. Następnie, po krótkim wprowadzeniu do twórczości Andrzeja Sapkowskiego, artykuł przedstawia sposoby, za pomocą których Wiedźmin 3 imituje topografię, architekturę, ludzką i pozaludzką działalność oraz dostarcza informacje o poszczególnych lokacjach. 0mówione właściwości tytułu sprawiają, że miejsca stworzone na potrzeby gry tworzą niezależny ontologiczny konstrukt, a nie wyłącznie szkielet umożliwiający rozgrywkę.

Słowa kluczowe: kreacja świata, gry wideo, Wiedźmin 